\title{
A Review of the Lithostratigraphy of the Early Cretaceous Sao Khua Formation, Khorat Group in Northeastern Thailand
}

\author{
Pradit Nulay1, Rungroj Arjwech ${ }^{2 *}$ \\ ${ }^{1}$ Office of Mineral Resources Region 2, Department of Mineral Resources, Ministry of Natural Resources and Environment, Khon \\ Kaen, Thailand \\ ${ }^{2}$ Department of Geotechnology, Faculty of Technology, KhonKaen University, Khon Kaen, Thailand \\ Email: ^rungroj@kku.ac.th
}

How to cite this paper: Nulay, P. and Arjwech, R. (2021) A Review of the Lithostratigraphy of the Early Cretaceous Sao Khua Formation, Khorat Group in Northeastern Thailand. Open Journal of Geology, 11, 381-395.

https://doi.org/10.4236/ojg.2021.119021

Received: July 18, 2021

Accepted: September 4, 2021

Published: September 7, 2021

Copyright $\odot 2021$ by author(s) and Scientific Research Publishing Inc. This work is licensed under the Creative Commons Attribution International License (CC BY 4.0).

http://creativecommons.org/licenses/by/4.0/

\begin{abstract}
Non-marine Cretaceous rocks are widespread in northeastern Thailand and is well known as "the red bed" Khorat Group. The Sao Khua Formation is in the upper half of the Khorat Group which is comprised of six formations. This formation was named and defined at the type section for the rocks between the restricted PhraWihan Formation and the Phu Phan Formation in the drainage area of the Huai Sao Khua, an intermittent stream that flows westward parallel to the highway between Nong Bua Lamphu and UdonThani Provinces. It contains richest and most diverse vertebrate and invertebrate Mesozoic fossils in Thailand. The Sao Khua Formation is characterized by the sequence of the fining-upward successions of at least $4-5$ megacycles throughout the formation with the total thickness ranging between $400-700$ meters. Each cycle starts with a channel lag conglomerate which the clasts consist totally of re-worked calcrete nodules. The conglomerates were overlain by fine- to medium-grained sandstones of point bar deposit. Finally, the top part of each cycle was covered by a succession of fine-grained floodplain deposit that makes up $60 \%-70 \%$ of the formation. Paleosols are commonly found in the Sao Khua Formation within the floodplain sequence and their geochemistry indicates a semi-arid paleoclimate. Based on lithostratigraphy, the Sao Khua Formation is interpreted to have been deposited by a meandering river system under a semi-arid climate condition. The age of the formation is assigned as the Hauterivian - Late Barremian based on vertebrate and bivalves fossils.
\end{abstract}

\section{Keywords}

Khorat Group, Sao Khua Formation, Lithostratigraphy, Non-Marine Cretaceous 


\section{Introduction}

The Cretaceous rocks in Thailand are widespread in Northeastern Thailand and are all non-marine sediments. They are composed of Phu Kradung, Phra Wihan, Sao Khua, Phu Phan, Khok Kruat, Maha Sarakham, and Phu Tok Formations in ascending order. One of the Sao Khua Formation is the richest and contains the most diverse vertebrate and invertebrate Cretaceous fossils in Thailand. Bivalves were the first fauna studied by Japanese workers [1]. Later on, the vertebrate and other fossils have been reported. However, most of the papers do not clearly demonstrate which part of the Sao Khua Formation contains the fossil samples. So, the aim of this paper is to review the lithostratigraphy of the Sao Khua Formation by compiling previous works together with some field checking in order to get a better understanding on the geology of the Sao Khua Formation which can contribute not only to the fossil studies but also for the paleoclimate and paleoenvironment of the Early Cretaceous.

\section{Geological Setting}

The geology of northeastern Thailand or the Khorat Plateau has been previously described (e.g. [2]-[11]). The stratigraphic sequence consists mainly of the Mesozoic non-marine red beds (Khorat Group), which is unconformably overlain by continental evaporites of the Maha Sarakham Formation and aeolian sandstone of the Late Cretaceous Phu Tok Formation. The group is underlain by the older rocks including the Late Triassic fluvial and lacustrine sediments of the HuaiHinLat Formation (Figure 1 and Figure 2). The igneous rocks, which are well exposed in the western region in the Loei - Phetchabun Fold Belt, are composed of both volcanic and plutonic rocks with a long age range from the Silurian to the Tertiary in age [12] [13] [14] [15] [16].

Generally, the Khorat Group comprises six formations, from bottom to top: Nam Phong, PhuKradung, PhraWihan, Sao Khua, Phu Phan, and KhokKruat (see Figure 1). The Nam Phong Formation varies in thickness from $2500 \mathrm{~m}$ in the central portion of the region to, thin or disappear along its flanks. [8] demonstrated that the Nam Phong Formation is divided into an Upper Nam Phong Formation and Lower Nam Phong Formation separated by an unconformity. Its stratigraphic successions are mainly of clastic sedimentary rock, consisting of reddish-brown micaceous sandstone, conglomerate, siltstone, and mudstone. The environment of deposition is considered as a fluviatile [17] commencing after the end of the deformation event (Indosinian II) of half graben basin of the HuaiHinLat Formation. The PhuKradung Formation varies from $1200 \mathrm{~m}$ in the basin centre to around $500 \mathrm{~m}$ in thickness on the basin flanks. The rocks consist predominantly of maroon siltstone while sandstone and conglomerate are subordinate. [18] has shown the coarsening-upward sequence throughout the formation on the basis of the subsurface study. The environmental deposition is considered as alluvial at the lower part and grade into fluvial in the upper part under meandering river system in semi-arid paleoclimate [18] [19] [20]. The 


\begin{tabular}{|c|c|c|c|c|c|}
\hline Group & Formation & Lithology & Descriptions & $\begin{array}{c}\text { Thickness } \\
\text { (m) }\end{array}$ & Age \\
\hline & Phu Tok & $\frac{1}{4-2}$ & $\begin{array}{l}\text { Red sandstone, siltstone, } \\
\text { claystone }\end{array}$ & $100-550$ & $\begin{array}{c}\text { Late } \\
\text { Cretaceous }\end{array}$ \\
\hline & $\begin{array}{l}\text { Maha } \\
\text { Sarakham }\end{array}$ & Find & $\begin{array}{l}\text { Brick-red siltstone and } \\
\text { sandstone, thick beds of rocksalt, } \\
\text { gypsum and anhydrite }\end{array}$ & $600-1000$ & $\begin{array}{l}\text { Mid-Late } \\
\text { Cretaceous }\end{array}$ \\
\hline
\end{tabular}

\section{Unconformity}

\begin{tabular}{|c|c|c|c|c|c|}
\hline \multirow{6}{*}{ Khorat } & Khok Kruat & $\frac{1}{40}$ & $\begin{array}{l}\text { Sequence of reddish-brown } \\
\text { sandstone and siltstone with } \\
\text { fossil of vertebrates }\end{array}$ & $430-700$ & $\begin{array}{c}\text { Early } \\
\text { Cretaceous }\end{array}$ \\
\hline & Phu Phan & की & $\begin{array}{l}\text { Sequence of greyish-white, } \\
\text { sandstone and conglomeratic } \\
\text { sandstone with plant remains }\end{array}$ & $80-140$ & $\begin{array}{c}\text { Early } \\
\text { Cretaceous }\end{array}$ \\
\hline & Sao Khua & & $\begin{array}{l}\text { Sequence of reddish-brown } \\
\text { sandstone, siltstone and } \\
\text { claystone; fossil of vertebrates } \\
\text { and bivalves }\end{array}$ & $400-720$ & $\begin{array}{c}\text { Early } \\
\text { Cretaceous }\end{array}$ \\
\hline & Phra Wihan & 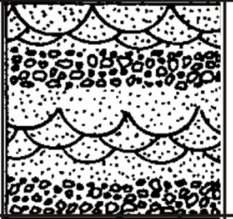 & $\begin{array}{l}\text { A sequence of whitish-grey } \\
\text { sandstone and conglomeratic } \\
\text { sandstone }\end{array}$ & $50-140$ & $\begin{array}{c}\text { Early } \\
\text { Cretaceous }\end{array}$ \\
\hline & $\begin{array}{l}\text { Phu } \\
\text { Kradung }\end{array}$ & and & $\begin{array}{l}\text { Sequence of maroon claystone } \\
\text { siltstone, sandstone and occasional } \\
\text { conglomerate; fossil of vertebrates } \\
\text { and bivalves }\end{array}$ & $800-1,100$ & $\begin{array}{l}\text { Middle Jurassic - } \\
\text { Early Cretaceous }\end{array}$ \\
\hline & $\begin{array}{l}\text { Nam } \\
\text { Phong }\end{array}$ & $\frac{1}{2+3}$ & $\begin{array}{l}\text { Reddish-brown sandstone, sitlstone } \\
\text { and claystone; fossil of dinosaurs }\end{array}$ & $100-1,500$ & $\begin{array}{l}\text { Late } \\
\text { Triassic }\end{array}$ \\
\hline
\end{tabular}

\section{Unconformity}

\begin{tabular}{|l|l|l|l|l|}
\hline Huai Hin & Sequence of fluvio-lacustrine & & \\
Lat & dark-grey mudstone, sandstone & Late \\
and occasion conglomerate & $100-400$ & Triassic \\
\hline
\end{tabular}

Figure 1. Stratigraphic column of the Mesozoic rocks of Northeastern Thailand (from [7]). 




Figure 2. Simplified geological map of Northeastern Thailand (from [28]).

PhuKradung Formation lies conformably on the upper Nam Phong and shows gradational contact with the overlying formation (the PhraWihan Formation). [21] assign the age of the PhuKradung Formation at the Late Jurassic - the Early Cretaceous based on the basis of palynological evidence. The PhraWihan Formation varies in thickness from around 50 to $300 \mathrm{~m}$. The rocks are composed entirely of white, coarse-grained, well-sorted texture, arkosic to orthoquartzitic. It is rare of siltstone, mudstone, and conglomerate. This dominant sandstone bed is interpreted to have been deposited by high energy, shallow braided stream with a subordinate meandering stream. The PhraWihan Formation is overlain conformably by the Sao Khua Formation and lies conformably on the PhuKradung Formation with age constraint at the Early Cretaceous (not older than Berriasian) [21]. The Sao Khua Formation varies widely in thickness from around 
100 to $700 \mathrm{~m}$. The successions of the Sao Khua Formation are generally composed of an alternation of reddish-brown conglomeratic sandstone with lime-nodule clasts, siltstone, and mudstone with calcrete and silcrete horizons at the base [1]. It was interpreted to have been deposited by low-energy of meandering stream and extensive flooding under warm and cool semi-arid paleoclimate. [21] suggested that the age of the Sao Khua Formation is the Berriasian-Barremian (the Early Cretaceous) based on the palynological data. The Phu Phan Formation is generally 50 - $100 \mathrm{~m}$ thick. It consists mainly of light-buff to brown, medium- to coarse-grained, well-sorted sandstone with sub-rounded texture. Siltstone and mudstone are rare but pebbly conglomerate with well-rounded quartz pebbles and subordinate mudstone intraclasts are found in several locations [20]. The presence of dominant sandstone beds is interpreted to have been deposited by high energy braided streams whilst subordinate fine-grained sediments represent floodplain deposits [20]. The KhokKruat Formation shows marked variations in thickness because of erosion, from $200 \mathrm{~m}$ in the NW to $850 \mathrm{~m}$ in the SE [8]. The rock consists mainly of light grey to light brown, thin- to thick-bedded, fine- to medium-grained micaceous or arkosic sandstone and often contains clay rip-up clasts. The sandstone beds are occasionally interbedded with siltstone and mudstone with subordinate conglomerate beds [22]. Subsequently, the sandstone beds generally show cross-bedding with some bi-directional cross laminations [20]. As a result, the formation was interpreted as deposited by predominantly meandering streams and on a floodplain. The KhokKruat Formation is overlain unconformably by the Maha Sarakham Formation and lies conformably on the Phu Phan Formation [23] [24] with a constrained age of the late Early Cretaceous (Aptian) [21].

In the Mid-Cretaceous, the inversion took place after the end of the Khorat Group accumulation [8] [24]. The inversion in the Mid-Cretaceous led to a restricted depositional basin containing red beds. Subsequently, the associated three rock salt layers of the Maha Sarakham Formation began to be deposited under a hypersaline land-locked, lacustrine basin in the arid condition of the mid-Cretaceous [1] [20]. The basin was subsequently covered by the PhuTok Formation in the Late Cretaceous under an arid desert environment [22] [25] [26]. Finally, in the Late Cretaceous to the Early Paleogene, the Southeast Asian region including Thailand was subject to strong deformation due to collision of the Greater India with the Eurasia [27]. The deformation produced large wave-length structures throughout the basin and formed the anticlinorium of the Phu Phan range.

\section{Lithostratigrapy of the Sao Khua Formation}

\subsection{Definition and Type Section}

The non-marine redbeds in northeastern Thailand have been studied for more than 60 years ago. The name Khorat Group is proposed for the group of the Mesozoic red beds deposited in northeastern Thailand or the Khorat Plateau. 
The group comprises six formations more than $3500 \mathrm{~m}$ thick. The Sao Khua Formation is one formation in the middle part of the group. It was named by [2] and it was defined at the type section for the rocks between the restricted PhraWihan Formation and the Phu Phan Formation in the drainage area of the Huai Sao Khua, an intermittent stream that flow westward parallel to the highway between Nong Bua Lamphu and UdonThani provinces.

\subsection{Lithology and Thickness}

Lithostratigraphically, based on the study of [2] the Sao Khua Formation is 512 $\mathrm{m}$ thick at the type section but it varies in another section from 404 to $720 \mathrm{~m}$. The rocks are characterized by fining upward sequence at least $4-5$ cycles of the meandering river deposits (Figure 3 ). The lower part of each cycle is characterized by channel lag deposits represented by a conglomerate with calcareous nodules or calcrete nodules are the main compositions of the clasts in the conglomerate. On top of the conglomerate is a point bar or channel bar sandstone. Finally, the sequence of flood plain deposits which comprise mainly of siltstone is lies on top of the point bar or channel bar sandstone of each cycle. It should be noted that the sandstone proportion is slightly higher at the lower and the upper parts of the formation (see Figure 3 ). It is characterized by yellowish-grey to yellowish-brown and pale red, fine- to medium-grain (Figure 4) while those at the middle part are reddish-brown. These features may be caused by the transition contrast between the Sao Khua Formation and lower and upper formation those PhraWihan and Phu Phan that are dominated by white quartzitic sandstone of braided stream river. The middle part of the formation is dominated by a succession of fined-grain, reddish-brown siltstone, and mudstone. As stated by [2] fined-grain clastic rocks make up $60 \%$ - 70\% of the formation but are seldom well exposed. Acalcrete horizon or lenticular caliche is usually evident on the top of the fined-grained clastic rocks succession. The sandstone beds are characterized by reddish-brown and pale red, fine- to medium-grain size. As stated by [7] the Sao Khua Formation is lithologically similar to the PhuKradung Formation being composed of reddish-brown fine- to medium-grained sandstone interbedded with fine-grained clastic rocks. The Sao Khua Formation in the eastern rim of the Khorat Plateau is sandier than in the western rim with its sedimentary structure(Figure 5) indicated the paleo-currents flowing from the east and northeast directed toward the west to the southwest [20] [29] [30].

\subsection{Depositional Environment and Paleoclimate}

The environment of deposition is interpreted to have been deposited by low energy meandering channel and extensive floodplain deposits with crevasse splay deposits in warm to slightly cool [31] semiarid conditions where the sediment were modified by pedogenesis [7]. Thinner sandstone beds are interpreted as crevasse splays, and those more than 1.5 meters thick represent meandering channels [21]. 


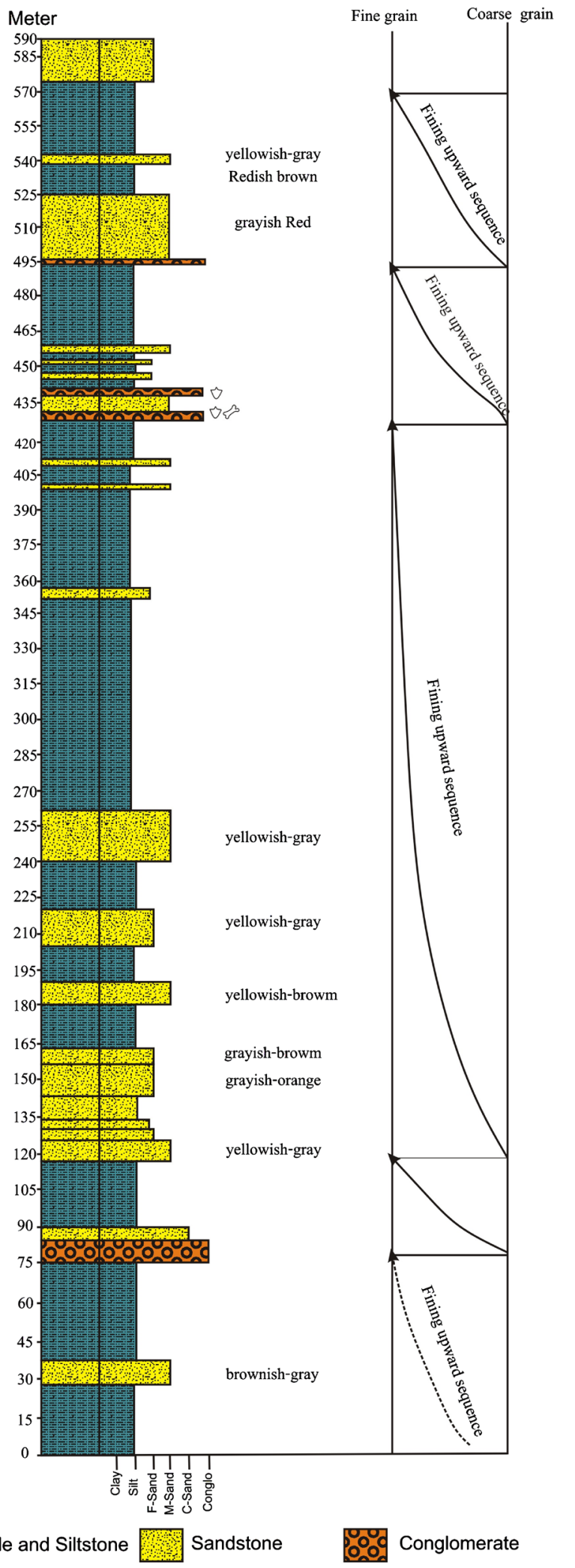

Figure 3. Stratigraphic column of Sao Khua Formation at the type section (slightly modified from [2] [29]). 

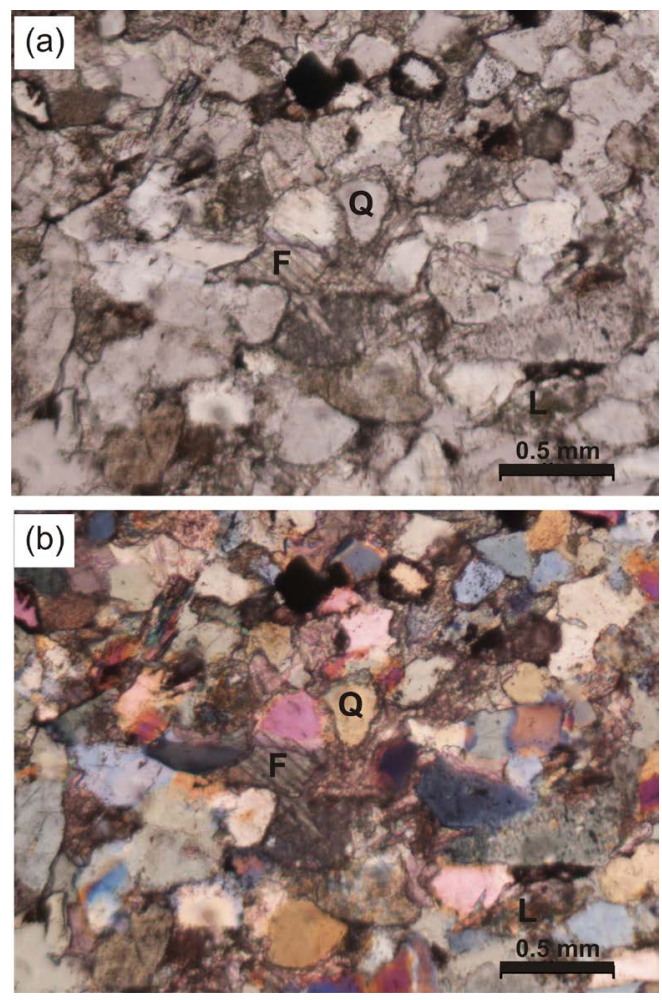

Figure 4. Photomicrographs of sandstones of the upper Sao Khua Formation. (a) fine- to medium-grain under plane polarized. (b) under cross polarized. Q. Quartz; F. feldspar; L. Lithic fragment. The sample location is at Wat KhaoKheeKatod, Khampha Ung, Phochai District, Roi-et Province. (Grid reference 16.446N, 1.3.815E)

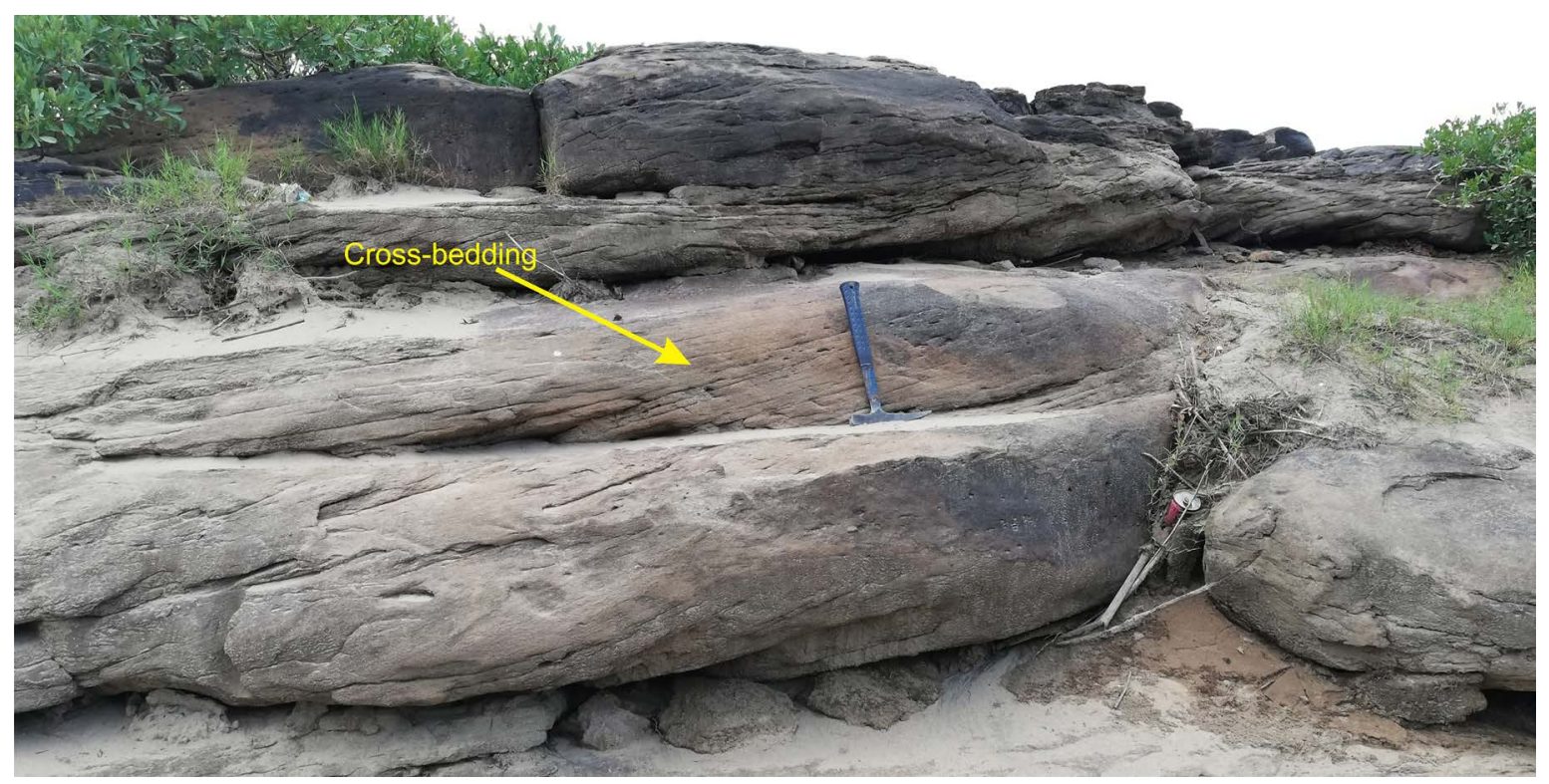

Figure 5. Thick bedded with cross-bedding sandstone of the upper Sao Khua Formation in the eastern rim of the Khorat Plateauat the Mekong River bank, Pho Sai District, UbonRatchathani Province. (Grid reference 15.752N, 105.135E)

As stated by [7] the Sao Khua Formation contains paleosols that are formed at the topmost part of each fining-upward cycle. Paleosols in the Sao Khua Forma- 
tion range in thickness from $0.5-5 \mathrm{~m}$ (average $2 \mathrm{~m}$ ) and consist of the horizon with calcrete and siltcrete nodules ranging in diameter from $0.3-5 \mathrm{~cm}$. In some places, paleosols were eroded and calcrete nodules re-deposited as channel conglomerate (Figure 6). [7] stated that the paleosols in the Sao Khua Formation are calcic and in general calcic paleosols are found in arid to semi-arid environments [1]. This point of view is supported by geochemical and petrography of the siltcrete in the Sao Khua Formation. As reported by [7] the Titanium dioxide $\left(\mathrm{TiO}_{2}\right)$ of siltcrete in the Sao Khua Formation is less than $0.03 \%$ in which the humid environment has a high concentration of $\mathrm{TiO}_{2}(>0.2 \%)$. Additionally, the feature of the petrography of the siltcrete in the humid environment such as void fills fibrous chalcedony, microcrystalline quartz, and colloform structures are absent. [1] concludes that the Sao Khua Formation was deposited by meandering river system under a semi-arid paleoclimate.

\subsection{Fossil Assemblage and Age}

The Sao Khua Formation not only contains the richest and most diverse of vertebrate fossils but invertebrates are also found. Isolated teeth of five hybodont taxa Hybodus sp., Parvodus sp., Lonchidion khoratensis nov. sp., Isanodus paladeji nov. gen., nov.sp., Heteroptychodus steinmanni have been described from the Sao Khua Formation by [32]. Five new species of dinosaur both theropod and sauropod are reported from the formation including Siammosaurus sutheethorni [33], Phuwianggosaurus sirindhornae [34], Siammotyrannus isanensis [35], Kinnareemimus khonkaenensis [36], Phuwiangvenator yaemniyomi and Vayuraptor nongbualumphuensis [37]. The fossil woods Agathoxylon saravanensis, and the adocidturtle Isanemys srisuki, the carettochelyid Kizylkumemys sp. and undetermined Trionychoidea have been reported by [38] and [39]. Freshwater bivalves are also abundant in the formation particularly the superfamily Trigonioidacea [40] [41]. As stated by [42] the presence of Koreanaia (Eokoreanaia)

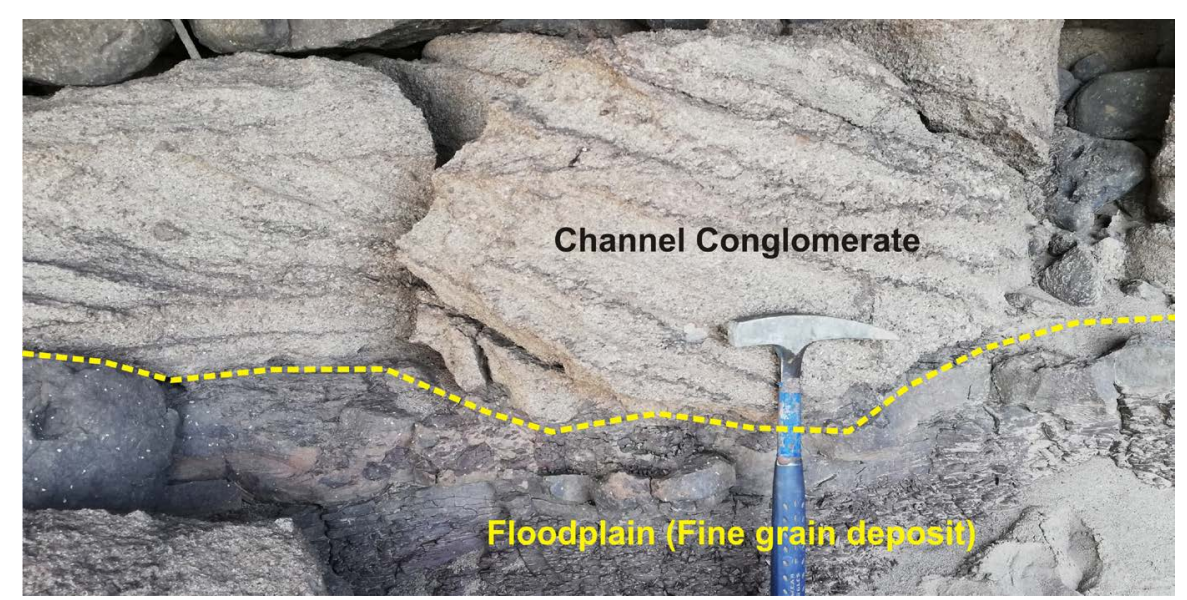

Figure 6. Photograph of channel lag conglomerate overlying on the floodplain deposit exposed at the Mekong River bank at Ban Song Khon, Pho Sai District, Ubon Ratchathani Province. Yellow line is sharp erosive contact between conglomerate and floodplain deposit. (Grid reference $15.844 \mathrm{~N}, 105.378 \mathrm{E}$ ) 
sp. - Yunannoconcha sp. assemblage in the lower part of Sao Khua Formation indicate the Hauterivian - Early Barremian age while those the upper part is dominated by Pseudohyria (Matsumotoina) somanai - Trigonioidoidea fam. indet assemblage indicating the Late Barremian.

\subsection{Contact}

As mentioned by [7] the Sao Khua Formation starts with rocks that consist of an alternation of reddish-brown silty claystone, siltstone, and fine- to mediumgrained sandstone. However, in the eastern rim of the Khorat Plateau, the Sao Khua Formation starts with the grayish-brown, fine, cross-laminated sandstone. Theses rock types are underlain conformably by the white quartzitic sandstone of the PhaWihan Formation. In the eastern rim of the Khorat Plateau, the contact gradually change from the white, cross-bedded, quartzitic sandstone of the underlying PhaWihan Formation to the grayish to reddish-brown, cross-laminated sandstone of the Sao Khua Formation (Figure 7).

The upper contact of the Sao Khua Formation is conformably overlain by the Phu Phan Formation. In places, the formation show a sequence of fining-upward sequence with the channel lag conglomerate, lateral migration of point bar sandstone and finally covered by reddish-brown siltstone with thinning-upward of floodplain deposit before it is conformably overlain by the light grey, conglomeratic sandstone of the Phu Phan Formation (Figure 8).
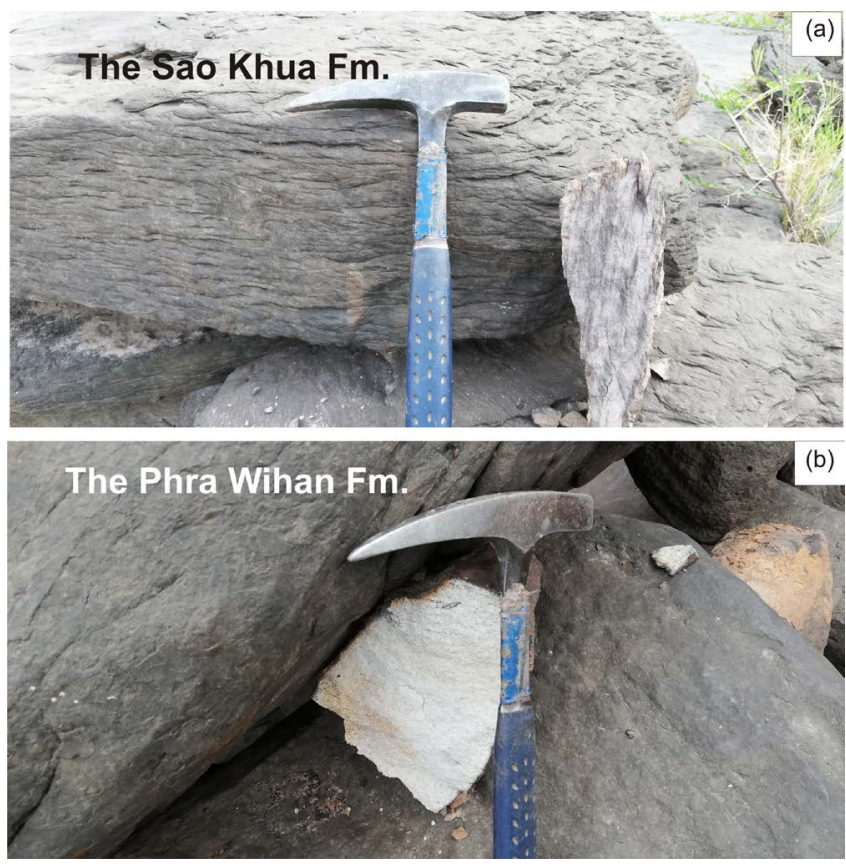

Figure 7. Photographs of the lower contact of the Sao Khua Formation with the underlying PhraWihan Formation. There are two contrast colour and grain size between the PhraWihan and Sao KhuaFms. (a) grayish brown, fine- to medium-grained, cross-laminated sandstone of the Sao Khua Formation (b) white, medium- to coarse-grained sandstone of the PhraWihan Formation. Both are at Mekong river bank, Ban Song Khon, Pho Sai District, UbonRatchathani Province. (Grid reference 15.848N, 105.374E). 

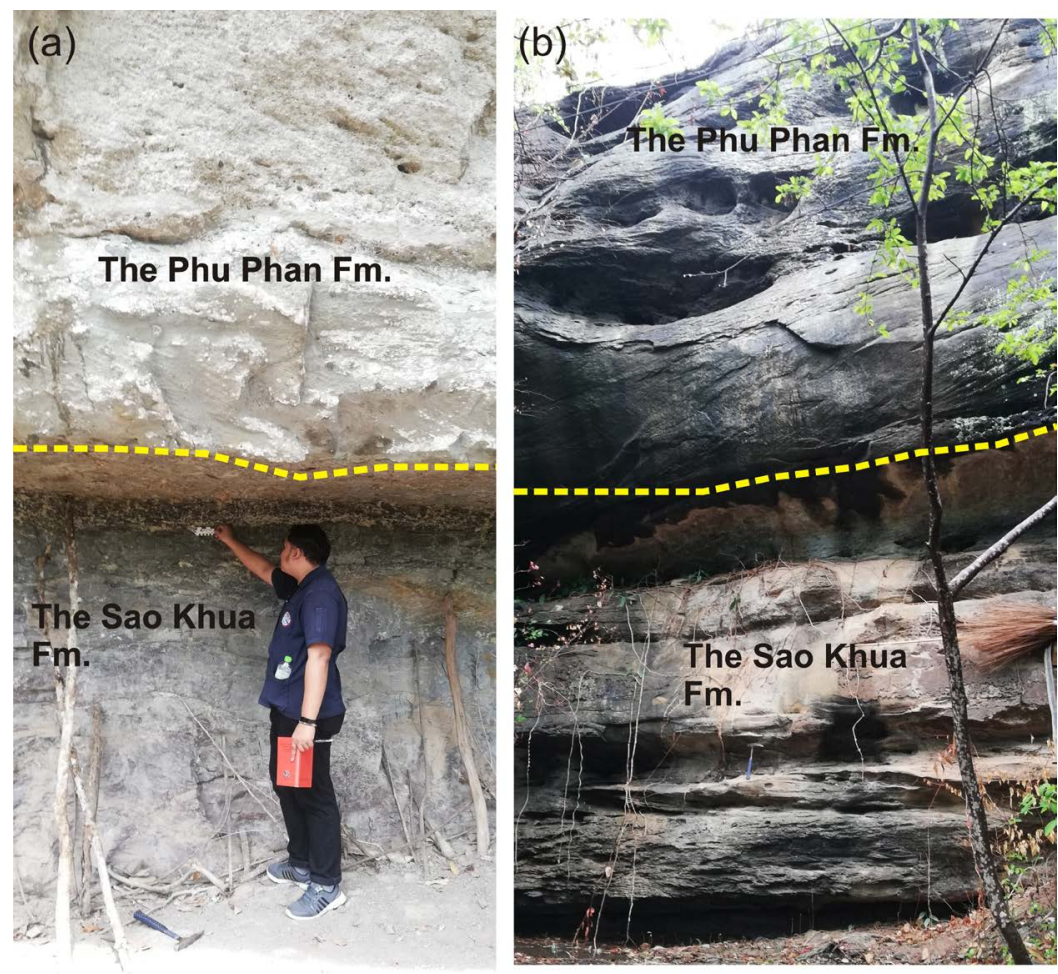

Figure 8. Photographs of the upper contact of the Sao Khua Formation with the overlying Phu Phan Formation (a) at the ThamHin So, Khampha Ung, Phochai District, Roi-et Province (Grid reference 16.432N, 103.855E) (b) at Wat KhaoKheeKatod, Khampha Ung, Phochai District, Roi-et Province.(Grid reference 16.446 N, 103.815E).

\section{Conclusions}

The Sao Khua Formation was named and defined at the type section for the rocks between the restricted PhraWihan Formation and the Phu Phan Formation in the drainage area of the Huai Sao Khua, an intermittent stream that flows westward parallel to and north of the highway between Nong Bua Lamphu and UdonThani Provinces. It is characterized by the sequence of the fining-upward sequence at least $4-5$ megacycles throughout the formation with the total thickness ranging between $400-700$ meters. Each cycle starts with a channel lag conglomerate and the clasts are mainly composed of re-work calcrete nodules. The conglomerates were overlain by fine- to medium-grained sandstones of point bar deposits. Finally, the top part of the cycle was covered by the succession of fine-grained floodplain deposits that makes up $60 \%-70 \%$ of the formation. Paleosols are commonly found in the Sao Khua Formation within the floodplain sequence and their geochemistry indicates a warm to slightly cool semi-arid paleoclimate. Based on lithostratigraphy, the Sao Khua Formation is interpreted to have been deposited by meandering river system under semi-arid condition. The Sao Khua Formation contains the richest and most diverse vertebrate and invertebrate Cretaceous fossils in Thailand. The age of the formation is assigned as the Hauterivian - Late Barremian based on the vertebrate and bivalves fossils. 


\section{Acknowledgements}

This study is financially supported by the Department of Mineral Resources, Bangkok, Thailand and the Department of Geotechonology, Faculty of Technology, KhonKaen University. The author is grateful to the Director General of the Department of Mineral Resources and the dean of the Faculty of Technology, KhonKaen University for their support and encouragement. We are grateful to three anonymous reviewers for their constructive and valuable reviews which greatly improved the manuscript.

\section{Conflicts of Interest}

The authors declare no conflicts of interest regarding the publication of this paper.

\section{References}

[1] Meesook, A. (2000) Cretaceous Environments of Northeastern Thailand. In: Hakuyu, O. and Nlall, J.M., Eds., Developments in Palaeontology and Stratigraphy, Elsevier, Amsterdam, 207-223. https://doi.org/10.1016/S0920-5446(00)80034-5

[2] Ward, D.E., and Bunnag, D. (1964) Stratigraphy of the Mesozoic Khorat Group in Northeastern Thailand. Report of Investigation No. 6, Department of Mineral Resources, Bangkok, $95 \mathrm{p}$.

[3] Sattayarak, N. (1983) Review of the Continental Mesozoic Stratigraphy of Thailand. Proceedings of the Workshop on Stratigraphy Correlation of Thailand and Malaysia, Haad Yai, 8-10 September 1983.

[4] Sattayarak, N., Chaisilboon, B., Srikulwong, S., Charusisawat, R., Mahattanachai, T., and Chantong (1998) Tectonic Evolution and Basin Development of the Northeast, Thailand. Seminar on Mesozoic Redbeds in the Northeastern Thailand, Bangkok, 1-20.

[5] Mouret, C., Heggemann, H., Gouadain, J., and Krisadasima, S. (1993) Geologic History of the Siliciclastic Mesozoic Strata of the Khorat Group in the Phu Phan Range Area, Northeastern Thailand. Conference the Biostratigraphy of Mainland Southeast Asia: Facies and Paleontology, Chiang Mai, February 1993.

[6] Mouret, C. (1994) Geologic History of Northeastern Thailand since the Carboniferous Relations with Indochina and Carboniferous to Early Cenozoic Evolution Model. Proceeding of International Symposium on Stratigraphic correlation of Southeast Asia, Bangkok, 15-20 November 1994.

[7] Meesook, A. (2001) Jurassic-Cretaceous Environment of Northeastern Thailand. Technical Report No.GSD 246/2001, Geological Survey Division, Department of Mineral Resources, Bangkok.

[8] Racey, A. (2009) Mesozoic Red Bed Sequences from SE Asia and the Significance of the Khorat Group of NE Thailand. In: Buffetaut, E., Cuny, G., Leloeuff, J. and Suteethorn, V., Eds., Late Palaeozoic and Mesozoic Ecosystems in SE Asia: The Geological Society, Special Publications, London, 41-67. https://doi.org/10.1144/SP315.5

[9] Cooper, M., Herbert, R. and Hill, G. (1989) The Structural Evolution of Triassic Intermontane Basin in Northeastern Thailand. Conference the Biostratigraphy of mainland Southeast Asia: Facies and Paleontology, Chiang Mai, 231-242.

[10] Carter, A. and Bristow, C. (2003) Linking Hinterland Evolution and Continental 
Basin Sedimentation by Using Detrital Zircon Thermochronology: A Study of the Khorat Plateau Basin, Eastern Thailand. Basin Research, 15, 271-285. https://doi.org/10.1046/j.1365-2117.2003.00201.x

[11] Piyasin, S. (1985) Problems of Stratigraphic Classification and Environments of Khorat Group. Conference on Geology and Mineral Resources Development of the Northeast Thailand, KhonKaen, 84-97.

[12] Kamvong, T., Khin, Z., Meffre, S., Maas, R., Stein, H. and Lai, C.K. (2014) Adakites in the Truong Son and Loei Fold Belts, Thailand and Laos: Genesis and Implications for Geodynamics and Metallogeny. Gondwana Research, 26, 165-184. https://doi.org/10.1016/j.gr.2013.06.011

[13] Khin, Z., Meffre, S., Lai, C.K., Burrett, C., Santosh, M., Graham, I., Manaka, T., Salam, A., Kamvong, T. and Cromie, P. (2014) Tectonics and Metallogeny of Mainland Southeast Asia-A Review and Contribution. Gondwana Research, 26, 5-30. https://doi.org/10.1016/j.gr.2013.10.010

[14] Salam, A., Khin, Z., Meffre, S., McPhie, J., and Lai, C.K. (2014) Geochemistry and Geochronology of the Chatree Epithermal Gold-Silver Deposit: Implications for the Tectonic Setting of the Loei Fold Belt, Central Thailand. Gondwana Research, 26, 198-217. https://doi.org/10.1016/j.gr.2013.10.008

[15] Khositanont, S. (2008) Gold and Iron-Gold Mineralization in the Sukhothai and Loei-Phetchabun Fold Belt. PhD Thesis, Chiang Mai University, Chiang Mai.

[16] Intasopa, S.B. (1993) Petrology and Geochonology of the Volcanic Rock of the Central Thailand Volcanic Belt. PhD Thesis, University of New Brunswick, Canada.

[17] Chonglakmani, C. (2011) Triassic. In: Ridd, M.F., Barber. A.J. and Crow, M.J., Eds., The Geology of Thailand, The Geological Society of London, London.

[18] Booth, J. and Sattayarak, N. (2011) Subsurface Carborniferouse-Cretaceous Geology of Northeast Thailand. In: Ridd, M.F., Barber, A.J. and Crow, M.J., Eds., The Geology of Thailand. The Geological Society of London, London.

[19] Meesook, A. and Saengsrichan, W. (2011) Jurassic. In: Ridd, M.F., Barber, A.J. and Crow, M.J., Eds., The Geology of Thailand. The Geological Society of London, London.

[20] Racey, A., Love, M., Canham, A., Goodall, J., Polachan, S. and Jones, P. (1996) Stratigraphy and Reservoir Potential of the Mesozoic Khorat Group, NE Thailand: Part 1: Stratigraphy and Sedimentary Evolution. Journal of Petroleum Geology, 19, 5-39. https://doi.org/10.1111/j.1747-5457.1996.tb00511.x

[21] Racey, A. and Goodall, J.G.S. (2009) Palynology and Stratigraphy of the Mesozoic Khorat Group Red Bed Sequences from Thailand. In: Buffetaut, E., Cuny, G., Leloeuff, J. and Suteethorn, V., Eds., Late Palaeozoic and Mesozoic Ecosystems in SE Asia. Special Publications, London, 69-83. https://doi.org/10.1144/SP315.6

[22] Meesook, A. (2011) Cretaceous. In: Ridd, M.F., Barber, A.J. and Crow, M.J., Eds., The Geology of Thailand, The Geological Society of London, London.

[23] Sattayarak, N. and Polachan, S. (1990) Rocksalt Underneath the Khorat Plateau. Proceedings of the Department of Mineral Resources Technical Conference, Bangkok, 2-6 July 1990, 1-14.

[24] Lovatt Smith, P.F., Stokes, R.B., Bristow, C. and Carter, A. (1996) Mid-Cretaceous Inversion in the Northern Khorat Plateau of Lao PDR and Thailand. In: Hall, R. and Blundell, D., Eds., Tectonic Evolution of Southeast Asia, Geological Society London, Special Publication, London, 233-247.

https://doi.org/10.1144/GSL.SP.1996.106.01.15 
[25] Hasegawa, H., Imsamut, S., Charusiri, P., Tada, R., Horiuchi, Y. and Hisada, K. (2010) "Thailand Was a Desert" during the Mid-Cretaceous: Equatorward Shift of the Subtropical High-Pressure Belt Indicated by Eolian Deposits (Phu Thok Formation) in the Khorat Basin, Northeastern Thailand. Island Arc, 19, 605-621. https://doi.org/10.1111/j.1440-1738.2010.00728.x

[26] Hasegawa, H., Tada, R., Jiang, X., Suganuma, Y., Imsamut, S., Charusiri, P., Ichinnorov, N. and Khand, Y. (2012) Drastic Shrinking of the Hadley Circulation during the mid-Cretaceous Supergreenhouse. Climate of the Past Discussions, 8, 1323-1337. https://doi.org/10.5194/cp-8-1323-2012

[27] Morley, C.K. (2012) Late Cretaceous-Early Palaeogene Tectonic Development of SE Asia. Earth-Science Reviews, 115, 37-75. https://doi.org/10.1016/j.earscirev.2012.08.002

[28] Department of Mineral Resources (Cartographer) (1999) Geological Map of Thailand; Scale 1: 2,500,000. Department of Mineral Resources, Sunnyside.

[29] Heggemann, H. (1994) Sedimentare Entwicklung der Khorat-Gruppe (ober-Trias bis Paleogen) in NE- und N-Thailand. Geologische Institute, Universitat Gottingen, Gottingen.

[30] Heggemann, H., Helmcke, D. and Tietze, K.W. (1994) Sedimentary Evolution of the Mesozoic Khorat Basin in Thailand. Geol.Palaont Teil l, 1992, 1267-1285.

[31] Amiot, R., Wangb, X., Zhoua, Z., Wanga, X., Buffetautc, E., Lécuyerd, C., Dingb, Z., Fluteaue, F., Hibinof, T., Kusuhashig, N., Moh, J., Suteethorni, V., Wang, Y., Xua, X. and Zhang, F. (2010) Oxygen Isotopes of East Asian Dinosaurs Reveal Exceptionally Cold Early Cretaceous Climates. Proceedings of the National Academy of Sciences of the United States of America, 108, 5179-5183.

https://doi.org/10.1073/pnas.1011369108

[32] Cuny, G., Suteethorn, V., Kamha, S., Buffetaut, E. and Philippe, M. (2006) A New Hybodont Shark Assemblage from the Lower Cretaceous of Thailand. Historical Biology, 18, 21-31. https://doi.org/10.1080/08912960500510495

[33] Buffetaut, E. and Ingavat, R. (1986) Unusaultheropod Dinosaur Teeth from the Upper Jurassic of Phu Wiang Northeastern Thailand. Revue De Paleobiologie, 5, 217-220.

[34] Martin, V., Buffetaut, E. and Suteethorn, V. (1994) A New Genus of Sauropod Dinosaur from the Sao Khua Formation (Late Jurassic or Early Cretaceous) of Northeastern Thailand. Comptes Rendus de PAcadémie des Sciences de Paris, 319 , 1085-1092.

[35] Buffetaut, E., Suteethorn, V. and Tong, H. (1996) The Earliest Known Tyrannosaur from the Lower Cretaceous of Thailand. Letter Nature, 381, 689-691.

https://doi.org/10.1038/381689a0

[36] Buffetaut, E., Suteethorn, V. and Tong, H. (2009) An Early “Ostrich Dinosaur" (Theropoda: Ornithomimosauria) Fromthe Early Cretaceous Sao Khua Formation of NE Thailand. In: Buffetaut, E., Cuny, G., Leloeuff, J. and Suteethorn, V., Eds., Late Palaeozoic and Mesozoic Ecosystems in SE Asia, the Geological Society, Special Publications, London, 229-243. https://doi.org/10.1144/SP315.16

[37] Samathi, A., Chanthasit, P. and Sander, M. (2019) Two New Basal Coelurosauriantheropod Dinosaurs from the Lower Cretaceous Sao Khua Formation of Thailand: Acta Palaeontologica Polonica, 64, 239-260. https://doi.org/10.4202/app.00540.2018

[38] Philippe, M., Jintasakul, P. and Boonchai, N. (2015) New Fossil Woods from the Mesozoic Khorat Group of Thailand and Their Palaeoecological Implications. Research and Knowledge, 1, 33-38. 
[39] Tong, H., Claude, J., Suteethorn, V., Naksri, W. and Buffetaut, E. (2009) Turtle Assemblages of the Khorat Group (Late Jurassic-Early Cretaceous) of NE Thailand. In: Buffetaut, E., Cuny, G., Leloeuff, J. and Suteethorn, V., Eds., Late Palaeozoic and Mesozoic Ecosystems in SE Asia, the Geological Society, Special Publications, London, 141-152. https://doi.org/10.1144/SP315.11

[40] Tumpeesuwan, S. (2010) Paleontology of the Early Cretaceous Non-Marine Molluscan Assemblages from the Sao Khua Formation in Nong Bua Lamphu, PhuWiang and SahatSakhan Areas Northeastern Thailand. PhD Thesis, Chulalongkorn University, Bangkok.

[41] Sha, J.G., Meesook, A. and Nguyen, X.K. (2012) Non Marine Cretaceous Bivalve Biostratigraphy of Thailand, Southern Lao PDR and Central Vietnam. Journal of Stratigraphy, 36, 382-399.

[42] Tumpeesuwan, S., Sato, Y. and Nakhapadungrat, S. (2010) A New Species of Pseudohyria (Matsumotoina) (Bivalvia: Trigonioidoidea) from the Early Cretaceous Sao Khua Formation, Khorat Group, Northeastern Thailand. Tropical Natural History, 10, 93-106. 